\title{
Correction to: Validation and Comparison of Instrumented Mouthguards for Measuring Head Kinematics and Assessing Brain Deformation in Football Impacts
}

\author{
Yuzhe Liu (1), ${ }^{1}$ August G. Domel, ${ }^{1}$ Seyed Abdolmajid Yousefsani, ${ }^{1}$ \\ Jovana Kondic, ${ }^{1,2}$ Gerald Grant, ${ }^{3,4}$ Michael Zeineh, ${ }^{5}$ \\ and David B. Camarillo ${ }^{1,3,6}$
}

\begin{abstract}
${ }^{1}$ Department of Bioengineering, Stanford University, Stanford, CA 94305, USA; ${ }^{2}$ Department of Electrical Engineering, Princeton University, Princeton, NJ 08540, USA; ${ }^{3}$ Department of Neurosurgery, Stanford University, Stanford, CA 94305,

USA; ${ }^{4}$ Department of Neurology, Stanford University, Stanford, CA 94305, USA; ${ }^{5}$ Department of Radiology, Stanford University, Stanford, CA 94305, USA; and ${ }^{6}$ Department of Mechanical Engineering, Stanford University, Stanford, CA 94305, USA
\end{abstract}

CORRECTION TO:

ANNALS OF BIOMEDICAL ENGINEERING

VOLUME 48, PAGES 2580-2598 (2020)

https://doi.org/10.1007/s10439-020-0269-3

This erratum is to correct the description about SWA mouthguard accuracy in the 6th sentence of the 11th paragraph (starting with "In summary, ") in the Discussion section. Since no criterion was set, the sentence "The SWA mouthguard was found to fail in providing reliable measurements of the linear acceleration at CoG," should be changed to "The SWA mouthguard was found to provide linear acceleration at CoG with relatively high error,". Then, the following sentence about the information of SWA mouthguard should be added after the 1st sentence of the 10th paragraph in the Discussion Section. "The SWA mouthguard does not have a filter, unlike the MiG and PRE mouthguards which do (Table 2)". Additionally, the row about the filter information should be added at the bottom of Table 2:

This erratum is also to correct the corresponding author as Yuzhe Liu.

Address correspondence to Yuzhe Liu, Department of Bioengineering, Stanford University, Stanford, CA 94305, USA. Electronic mail: yuzheliu@stanford.edu

The original article can be found online at https://doi.org/10. 1007/s10439-020-0269-3. 
TABLE 2. Parameters and specifications corresponding to the MiG, PRE, and SWA mouthguards, as well as the reference ATD.

\begin{tabular}{|c|c|c|c|c|}
\hline & $\begin{array}{l}\text { Stanford mouthguards } \\
\text { (MiG-C and MiG-B) }\end{array}$ & $\begin{array}{l}\text { Prevent mouthguards } \\
\text { (PRE-C and PRE-B) }\end{array}$ & $\begin{array}{l}\text { Sports \& wellbeing analytics } \\
\text { mouthguard (SWA-C) }\end{array}$ & $\begin{array}{l}\text { ATD (Refer- } \\
\text { ence) }\end{array}$ \\
\hline $\begin{array}{l}\text { Sampling rate (Ac- } \\
\text { celerometer) }\end{array}$ & $1000 \mathrm{~Hz}$ & $3200 \mathrm{~Hz}$ & $1000 \mathrm{~Hz}$ & $100,000 \mathrm{~Hz}$ \\
\hline $\begin{array}{l}\text { Sampling rate (Gyro- } \\
\text { scope) }\end{array}$ & $8000 \mathrm{~Hz}$ & $3200 \mathrm{~Hz}$ & $952 \mathrm{~Hz}$ & $100,000 \mathrm{~Hz}$ \\
\hline $\begin{array}{l}\text { Measurement range (Ac- } \\
\text { celerometer) }\end{array}$ & $\pm 400 \mathrm{~g}$ & $\pm 200 \mathrm{~g}$ & $\pm 200 \mathrm{~g}$ & $\pm 500 \mathrm{~g}$ \\
\hline $\begin{array}{l}\text { Measurement range (Gy- } \\
\text { roscope) }\end{array}$ & $\pm 70 \mathrm{rad} / \mathrm{sec}$ & $\pm 35 \mathrm{rad} / \mathrm{s}$ & $\pm 35 \mathrm{rad} / \mathrm{s}$ & $\pm 140 \mathrm{rad} / \mathrm{s}$ \\
\hline Output time windows & {$[-49,150] \mathrm{ms}$} & {$[0,50] \mathrm{ms}$} & {$[1,103] \mathrm{ms}$} & $\begin{array}{l}{[-200,800]} \\
\quad \mathrm{ms}\end{array}$ \\
\hline $\begin{array}{l}\text { Output coordinate axes } \\
\text { direction }\end{array}$ & $X$-front, $Y$-left, $z$-top & $X$-front, $Y$-right, $z$-bottom & $\begin{array}{l}\text { Not parallel to standard coordi- } \\
\text { nate }\end{array}$ & $\begin{array}{l}X \text {-front, } Y \text {-right, } \\
Z \text {-bottom }\end{array}$ \\
\hline Output coordinate origin & Sensor & Center of Gravity (CoG) & Sensor & $\begin{array}{l}\text { Center of Grav- } \\
\text { ity (CoG) }\end{array}$ \\
\hline $\begin{array}{l}\text { Time windows after align- } \\
\text { ment processing }\end{array}$ & {$[-48,151] \mathrm{ms}$} & {$[-10,40] \mathrm{ms}$} & {$[-1,101] \mathrm{ms}$} & $\begin{array}{l}{[-200,800]} \\
\mathrm{ms}\end{array}$ \\
\hline $\begin{array}{l}\text { Cut-off frequency of the } \\
\text { filter }\end{array}$ & $160 \mathrm{~Hz}$ & $200 \mathrm{~Hz}$ & No filter & $300 \mathrm{~Hz}$ \\
\hline
\end{tabular}

In time windows after the alignment processing, $t=0 \mathrm{~ms}$ corresponds to the trigger-point of the ATD (absolute value of linear acceleration at CoG in any components reaches $10 \mathrm{~g}$ ), see "Materials and Methods" Section for information about the time alignment.

Publisher's Note Springer Nature remains neutral with regard to jurisdictional claims in published maps and institutional affiliations. 